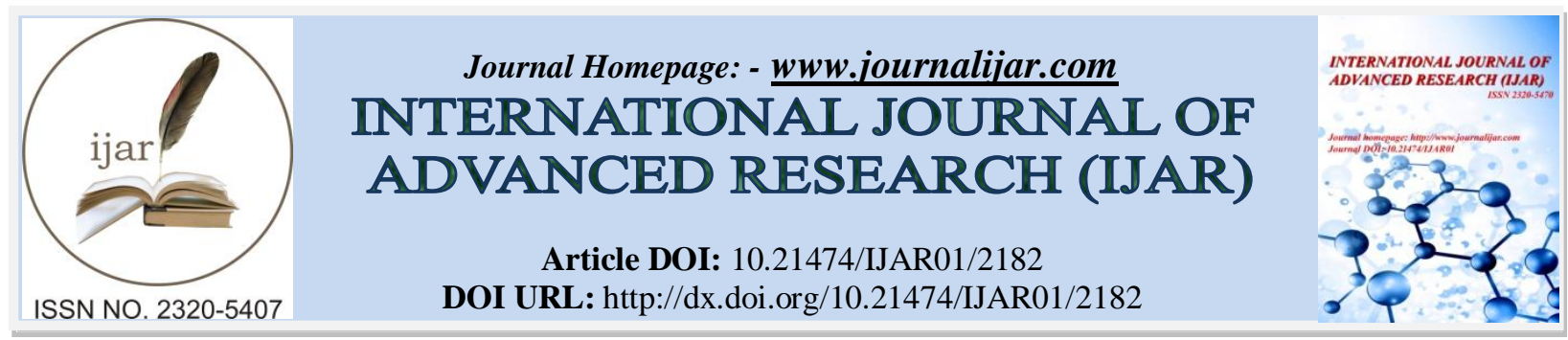

RESEARCH ARTICLE

\title{
EFFECT OF TREATED WASTE WATER ON COMPRESSIVE STRENGTH AND PERMEABILITY OF M25 GRADE CONCRETE.
}

Vivek Thakur ${ }^{1}$ and Dr. Hemant Sood ${ }^{2}$.

1. M.E. Scholar, Civil Engineering, NITTTR, Chandigarh, India.

2. Profesor and H.O.D. Civil Department, NITTTR, Chandigarh, India.

\section{Manuscript Info}

Manuscript History

Received: 26 September 2016

Final Accepted: 29 October 2016

Published: November 2016

Key words:-

Waste water, Water permeability,

Compressive Strength, Ordinary

Portland cements (OPC), Treated waste

water (TWW), Potable water (PW).

\section{Abstract}

The study presented in this paper discusses the suitability of using treated waste water for making concrete. Experiments conducted give us an idea about the compressive strength and water permeability for the M25 grade of concrete. For optimizing the use of treated waste water cube specimens were cast using variables proportions such as: $50 \%, 75 \%, 100 \%$ and comparison was done with potable water results. The compressive strength result for M25 grade concrete was highest corresponding to $100 \%$ addition of treated waste water. The average water permeability value for M25 grade concrete was lowest for $100 \%$ proportion of waste water. From the test results obtained, it is recommended to use $100 \%$ waste water for M25 grade concrete.

Copy Right, IJAR, 2016,. All rights reserved.

\section{Introduction:-}

After water most rapidly consumed material on the earth is concrete. We cannot stop the construction processes but yes we change the change the way they should be done keeping an eye on the resources we use. The construction process is growing day by day in exponential terms and so is the consumption of potable water. Hence it is of great concern to reduce the consumption of potable water and searching for its alternative. Use of waste water can be a boon in disguise.

With the increasing population the water consumption is also increasing and finally resulting in increased waste water generation. Managing waste water is one of the challenges nowadays. Scientifically the water to be used for concrete mixing has to satisfy a certain set of chemical properties as defined by BIS: 3025 hence waste water treated or untreated lying within the range of the qualifying chemical properties can be used flawlessly in concrete production.

The whole of the world is in search for various sustainable methods so that we can develop concrete without damaging the Mother Nature. Hence, need of the hour is to use the basic resources in a very efficient and nature friendly manner so that we can pass on a better place to live in for our future generations. Because no matter how much big amount of money we spend on sustainable technologies there can be no change if we fail to conserve the basic resources of nature. 
Table 1: - Chemical Properties of Treated Waste Water

\begin{tabular}{|l|l|l|l|l|}
\hline S. No. & Parameters & Potable Water $\mathbf{( m g / l ~ o r ~ m l ) ~}$ & $\begin{array}{l}\text { Treated Waste Water } \\
(\mathbf{m g} / \mathbf{l} \text { or ml })\end{array}$ & $\begin{array}{l}\text { Permissible } \\
\text { Limits }(\mathbf{m g} / \mathbf{l} \text { or } \\
\mathbf{m l})\end{array}$ \\
\hline 1 & pH & 7.49 & 7.24 & $>6$ \\
\hline 2 & DO & 7.38 & 6.83 & - \\
\hline 3 & COD & 10 & 196 & 3000 \\
\hline 4 & BOD & 6 & 140 & 200 \\
\hline 5 & TDS & 225 & 532 & 2000 \\
\hline 6 & Sulphate Content & 24.72 & 36.3 & 400 \\
\hline 7 & Chloride Content & 18.5 & 140 & 2000 \\
\hline 8 & Acidity & - & 3.5 & 5 \\
\hline 9 & Alkalinity & 11.5 & - & 25 \\
\hline
\end{tabular}

Materials And Methodology:-

Cement: Ultra-Tech OPC 43 grade conforming to BIS: 8112 was used for this project.

Water: The sewage treatment plant located at 3BRD Chandigarh was selected as suitable source of treated waste water used in this project. Laboratory tests for various properties as per BIS: 3025 were conducted in the institute's laboratory.

Coarse Aggregate: Aggregate conforming to BIS: 383-1970 was used in this project. Maximum size aggregate limited to $20 \mathrm{~mm}$ was mixed with $12 \mathrm{~mm}$ sized aggregate in proportion of $(1.5: 1)$ in order in order to make a well graded mix. Specific gravity- 2.74 .

Fine Aggregate: Locally available clean river sand having specific gravity value 2.65 conforming to zone III was used.

Mix Design: Mix design for M25, M30 and M35 grade concrete was carried out conforming to BIS: 10262-2009.

Casting: For both the compressive strength test and water permeability test a set of three $150 \mathrm{~mm}$ concrete cubes for each grade and proportion of waste water were cast as per the calculated mix proportion. For M25, M30 and M35 grade concrete cubes various waste water proportions used were as follows:

a) $100 \%$ treated waste water.

b) $75 \%$ treated waste water with $25 \%$ potable water.

c) $50 \%$ treated waste water with $50 \%$ potable water.

d) $100 \%$ potable water.

e)

Curing: Curing was done in the water tank filled with potable water maintained at $28 \pm 3^{\circ} \mathrm{C}$. The curing was done for variable days.

Compressive strength test: For compressive strength test cubes were tested at 28 day. The compression testing machine with a capacity of $3000 \mathrm{kN}$ was used to determine the compressive strength of concrete with a normal rate of loading that is $140 \mathrm{~kg} / \mathrm{cm}^{2} /$ minute.

Permeability test: This test was performed as per IS: 3085 . The standard pressure head to be applied should be $5 \mathrm{~kg} / \mathrm{cm}^{2}$ which may further be increased up to $7 \mathrm{~kg} / \mathrm{cm}^{2}$. The prepared cubes with chamfered faces were fitted in the mould and the gap between the cubes and the mould filled with wax so that no leakage of water through sides takes place. With the test assembly completely filled with water, the desired pressure head was applied to the water reservoir. A clean bottle was placed under permeability cell to measure the water percolating through the sample. Permeability test was continued for 100 hours after steady state flow has been achieved. 
Table 2: - Number of samples cast

\begin{tabular}{|l|l|l|}
\hline S.No & Waste water proportioning & Number of Samples(150 mm Cube) Cast \\
\hline 1. & $50 \%$ TWW $+50 \%$ PW & 6 \\
\hline 2. & $75 \%$ TWW $+25 \%$ PW & 6 \\
\hline 3. & $100 \%$ TWW & 6 \\
\hline 4. & $100 \%$ PW & 6 \\
\hline
\end{tabular}

\section{Results:-}

M25 Grade concrete:-

The average compressive strength and permeability test results $(\mathrm{m} / \mathrm{s})$ of specimens at 28 day curing for various percentage of treated waste water and potable water are depicted in the figure 1 .

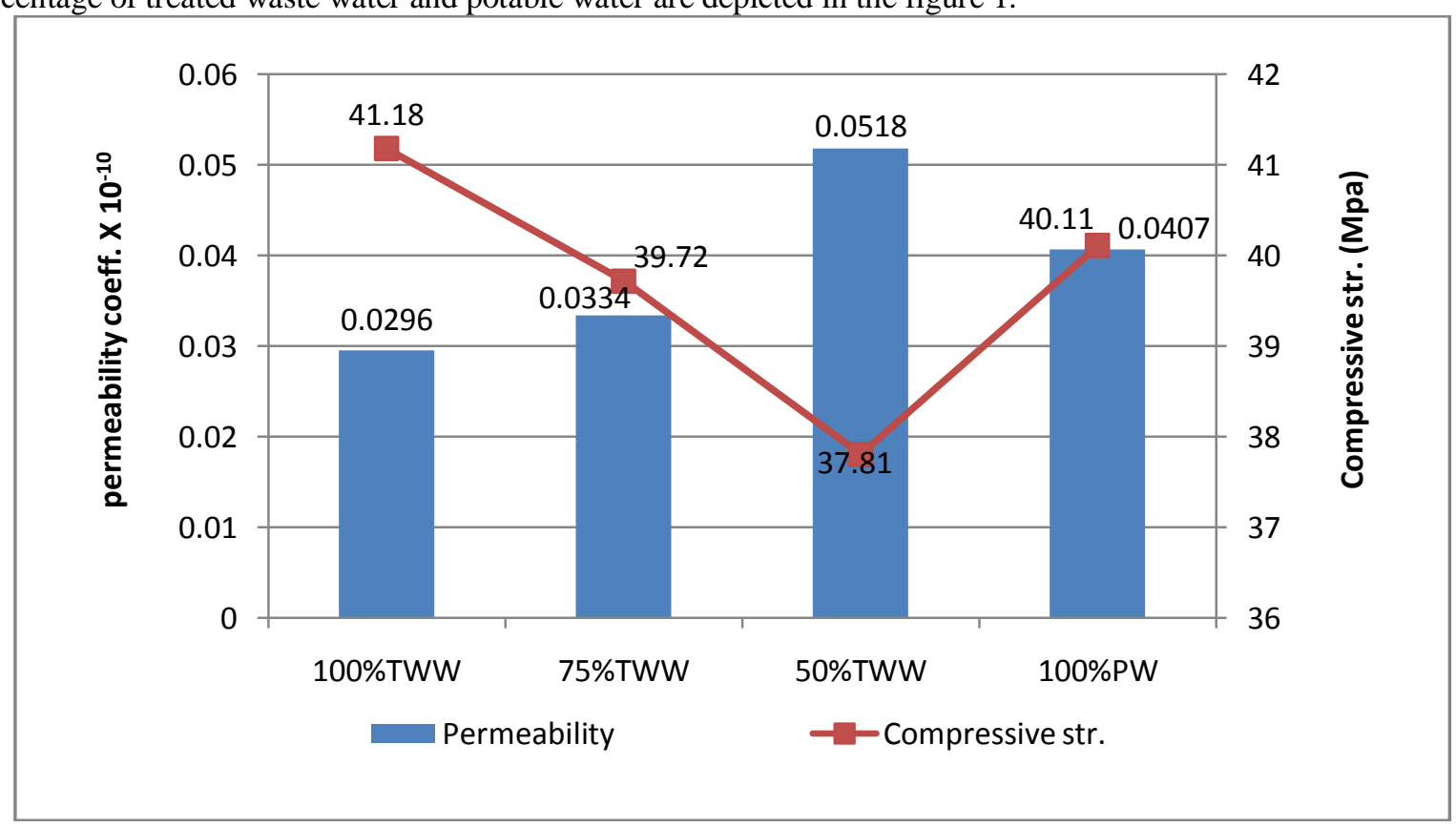

Fig. 1:- Compressive Strength and permeability results for M25

Compressive strength test results:-

Table 3: - Compressive strength (Mpa)

\begin{tabular}{|l|l|l|l|l|l|}
\hline Water Content $\rightarrow$ & 100\% TWW & $\begin{array}{l}\mathbf{7 5 \%} \text { TWW } \\
\mathbf{2 5 \%} \text { PW }\end{array}$ & $\begin{array}{l}\mathbf{5 0 \%} \text { TWW } \\
\mathbf{5 0 \%} \text { PW }\end{array}$ & $\mathbf{1 0 0 \%}$ PW \\
\hline Grade $\downarrow$ & & & & \\
\hline M25 & & 39.72 & 37.81 & 40.11 \\
\hline
\end{tabular}

Permeability test results:-

Table 4: -Coefficient of permeability, $\left(\mathrm{k} \mathrm{X} 10^{-10} \mathrm{~m} / \mathrm{s}\right.$ )

\begin{tabular}{|l|l|l|}
\hline S.No & Proportioning of water & $(\mathbf{K ~ X ~ 1 0}$ \\
\hline $\mathbf{1 .}$ & $50 \%$ TWW $/ \mathbf{s}) \mathbf{~ M 2 5 ~ G r a d e}$ \\
\hline $\mathbf{2 .}$ & $75 \%$ TWW $+25 \%$ PW & 0.0518 \\
\hline 3. & $100 \%$ TWW & 0.0334 \\
\hline $\mathbf{4 .}$ & $100 \%$ PW & 0.0296 \\
\hline
\end{tabular}

\section{Summary of the test results:-}

The compressive strength test results for M25 grade concrete cubes with 100\% TWW are much higher with respect to its target mean strength as calculated while designing the mix. The permeability coefficient values recorded are low which may be due to the dense pore structure. 


\section{Conclusions:-}

1) For M25 grade concrete the permeability values are lowest for $100 \%$ TWW.

2) The compressive strength results for M25 grade with $100 \%$ TWW are higher with respect to its target mean strength as per design mix.

3) According to the test results, the use of treated waste water can be recommended for use in Plain cement concrete.

\section{References:-}

1. Kucche K. J; Jamkar S. S; Sadgir P. A; "Quality of Water for Making Concrete: A Review of Literature",International Journal of Scientific and Research Publications, Vol. 5, Issue 1, January 2015.

2. Prema R; Gowthama Selvan M; "Studies on the Effect of Replacing Potable Water with Rice Mill processed water for the development of High Performance Concrete" National Conference On Research Advances In Communication, Computation, Electrical Science And Structures, 2015.

3. G. K. Arun; Vivek; T. Bragadeeswaran; A. Preetha; D. Mahendran; "Study on Behaviour of Paper Industry Treated Effluent as Mixing Water in Concrete for Pollution Control and Sustainable Development", International Journal of Engineering Research \& Technology, Vol. 3, Issue 8, pp. 1049-1051, 2014.

4. Karthikeyan M; Asha B; "Experimental Analysis of Regenerate the Treated Wastewater in Concrete", International Journal of World Research, Vol. 1, Issue 4, April 2014.

5. Kulkarni Vinut; Patil Suresh G; Shivasharanappa; "Study on Compressive Strength of Concrete by Using Treated Domestic Waste Water as Mixing and Curing of Concrete",IJRET: International Journal of Research in Engineering and Technology, Vol. 3, Issue 12, December 2014.

6. Murali G; Vardhan C.M.V; Raju S; Mahalakshmi C; Srinidhi G; Zachariah D. S; "Influence of various industrial effluents on concrete structures", International Journal of Engineering Research and Applications, Vol. 2, pp. 704-709, April 2012.

7. Al-Anzi Bader; Abusam Abdallah; ShahalamAbulbasher; "Assessment of Wastewater Reuse in Kuwait and its Impact on Amounts of Pollutants Discharged into the Sea",Journal of Environmental Protection, Vol. 3, pp. 935-939.

8. BintiRitzawaty; Shukeri Mohamad; Ghani A. Naser Abdul; "Concrete Mix with Wastepaper", 2nd International Conference on Built Environment in Developing Countries, ICBEDC 2008.

9. Cement Concrete \& Aggregates Australia, "Use of Recycled Water in Concrete Production".

10. M. McCarthy Leigh; "Analysis of Alternative Water Sources for Use in the Manufacture of Concrete", Thesis under Queensland University of Technology, School of Physical and Chemical Sciences.

11. Bureau of Indian Standards Plain and Reinforced Concrete Code of Practice, BIS: 456-2000.

12. Bureau of Indian Standards Guidelines for Concrete Mix Design Proportioning, BIS: 10262-2009.

13. Bureau of Indian Standards Method of Tests for Strength of Concrete, BIS: 516-1959. 